\title{
PENINGKATAN KECERDASAN LOGIKA- MATEMATIKA MELALUI BIBLIOTERAPI ANAK USIA DINI KELOMPOK A DI KOBER WARNA PLUS
}

\author{
Wanti Setiawati ${ }^{1}$, Ema Aprianti ${ }^{2}$ \\ ${ }^{1}$ Pendidikan Guru PAUD, IKIP Siliwangi \\ ${ }^{2}$ Pendidikan Guru PAUD, IKIP Siliwangi \\ 1anti70006@gmail.com, ${ }^{2}$ emaaprianti88@gmail.com \\ Received: XXXXX X, XXXX; Accepted: XXXXX X, XXXX
}

\begin{abstract}
The background of this research is the lack of logic-mathematical abilities of children, especially knowing the symbol of group A numbers in Kober Warna Plus. For this reason, bibliotherapy methods are needed to develop logical-mathematical intelligence This research method is descriptive and research form PTK with pre-school child subjects. Data collection techniques are observation, interviews, and documentation. Based on the results of the first cycle test and observation study of $12.5 \%$ of the children developed very well, $37.5 \%$ developed according to expectations, and 50\% began to develop and still had to be stimulated, but when the second cycle was tested, the result showed that the child had developed ability very good, namely $87.5 \%$, and $12.5 \%$ as expected.
\end{abstract}

Keywords: Logic-Mathematical Intelligence, Bibliotherapy, Early Childhood

\begin{abstract}
Abstrak
Penelitian ini dilatarbelakangi kurangnya kemampuan logika-matematika anak terutama mengenal lambang bilangan kelompok A di Kober Warna Plus.Untuk itu, diperlukan metode biblioterapi untuk meningkatkan kecerdasan logis-matematis anak. Metode penelitian ini merupakan deskriptif dan bentuk penelitiannya PTK dengan subjek anak pra sekolah.Teknik pengumpulan data yaitu observasi, wawancara, serta dokumentasi. Berdasarkan hasil penelitian tes dan observasi siklus I sebesar 12,5\% anak berkembangan sangat baik, 37,5\% berkembang sesuai harapan, serta $50 \%$ mulai berkembang dan masih harus distimulasi, namun saat dilakukan tes siklus II, hasilnya anak sudah menunjukkan kemampuannya
\end{abstract}

Kata Kunci: Kata Kunci, Kata Kunci, Kata Kunci

\section{PENDAHULUAN}

Secara psikologi dan ilmu pendidikan, masa keemasan (The Golden Age) usia nol sampai enam tahun adalahwaktu peletakan dasar atau fondasi awal bagi pertumbuhan dan perkembangan anak. Menurut penelitian di bidang neuro-sains yang dilakukan oleh Obson, White, dan Bloom (Suyadi \& Maulidya, 2013) menyatakan bahwa "perkembangan kecerdasan anak pada usia nol sampai empat tahun mencapai $50 \%, . . "$

Pada masa ini pertumbuhan serta perkembangan anak perlu distimulus untuk mengembangkan aspek-aspek pada anak. Untuk itulah pendidikan pra sekolah penting bagi masa peka anak, yaitu saat terjadinya pematangan fungsi fisik serta psikis yang siap merespon 
stimulus yang diberikan oleh lingkungan untuk meletakkan dasar pertama mengembangkan kemampuan fisik, bahasa, sosial, motorik, emosional, seni, moral, agama, dan intelektual, termasuk didalamnya kecerdasan majemuk. Multiple Intelligences yakni produk kajian Neurosains di bidang pendidikan yang ditemukan Howard Gardner, seorang ahli saraf dan psikologi terkemuka dari sekolah kedokteran Boston dan pendidikan Harvard pada tahun 1983. Gardner merupakan Co-direction pada Project Zero, sebuah kelompok reset di Harvard Graduate School of Education. Dari proyek penelitian inilah, Gardner menemukan kecerdasan majemuk.Salah satu Multiple Intelligencesadalah kecerdasan logika-matematika, yaitu "kecerdasan yang dimiliki anak terkait hal angka dan logika, yakni kecerdasan yang melibatkan keterampilan dalam mengolah/kemahiran menggunakan angka serta akal sehat. Kecerdasan logis-matematisAUD dikembangkan melalui: mengenal beberapa bilangan, beberapa pola, perhitungan, pengukuran, geometri, dan pengklasifikasian. Kemampuan kecerdasan logika-matematika anak ini bisa diidentifikasi melalui: 1) kemampuan menggunakan sistem angka yang abstrak; 2) kemampuan menemukan hubungan antara perilaku, objek, dan ide-ide; serta 3) keterampilan menggunakan alasan yang logis atau berurutan" (Sujiono \& Sujiono dalam Kurniawan, 2016: 83).

Cara terbaik belajar untuk kecerdasan ini melalui angka, berpikir, bertanya, mencoba, menduga, menghitung, menimbang, mengurutkan, mengklasifikasi, dan mengonstruksi. Materi pembelajaran logikamatematika berupa mengajukan pertanyaan kritis, mempolakan sesuatu misalnya mendesain bangunan dengan berbagai bentuk dan warna, membuat kode angka, atau simbol lainnya, mengukur, mengurutkan sesuatu atau mengirangira jumlah serta ukuran suatu benda. Materi untuk anak pra sekolah, kapasitas penggunaan angka-angka masih sebatas pengenalan konsep matematika sederhana.

Pengembangan kognitif bergayut erat dengan kecerdasan logis-matematis dan naturalis. Stimulasi kecerdasan logika-matematikaakan mendorong perkembangan intelektual, terutama kemampuan berpikir logis, mengolah informasi, kapasitas berpikir, memorisasi, penalaran, akuisisi konsep, klasifikasi, pemecahan masalah, serta pemusatan perhatian. Kemampuan kognitif merupakan tingkah laku yang mengakibatkan orang memperoleh wawasan atau yang dibutuhkan untuk menggunakan pengetahuan. Perkembangan intelektual menunjukkan perkembangan dari cara anak berpikir, termasuk kemampuan anak mengkoordinasikan berbagai cara berpikir menyelesaikan berbagai masalah yang dihadapi anak.

Aspek kecerdasan logika- matematika anak empat sampai lima tahun dalam perkembangan kognitif menurut Permendikbud RI No 137 (2014) yang akan dijadikan acuan untuk PTK ini sebagai berikut:

1. Belajar dan Pemecahan Masalah

a. Mengenal konsep sederhana kehidupan sehari-hari

b. Memahami pola kegiatan serta menyadari pentingnya waktu

c. Mengetahui konsep banyak dan sedikit

2. Berpikir Logis

a. Mengenal warna

b. Mengenal pola

c. Mengurutkan benda berdasarkan lima seriasi ukuran atau warna

3. Berpikir Simbolik

a. Menyebutkan lambang bilangan 1-10

b. Menggunakan lambang bilangan untuk menghitung

c. Mencocokkan bilangan dengan lambang bilangan

Kecerdasan logika-matematika setiap anak berbeda karena faktor yang memengaruhinya, antara lain: pembawaan, kematangan tiap organ tubuh mengalami pertumbuhan serta perkembangan, pembentukan keadaan di luar diri seseorang yang memengaruhi perkembangan kecerdasan, minat dan pembawaan yang khas, serta kebebasan manusia dapat memilih metodemetode tertentu dalam memecahkan masalah. Semua faktor itu bersangkutpaut satu sama lain. Untuk menentukan cerdas tidaknya seorang anak, bukan hanya berpedoman pada salah satu faktor saja. Kecerdasan adalah faktor total, yang berperan menentukan kecerdasan seseorang.

Untuk itu, kecerdasan ini menjadi aspek perkembangan yang harus dikembangkan di 
PAUD sebagai tuntutan sekolah dasar, yang mensyaratkan calon siswanya harus bisa baca, tulis, dan hitung. Akibatnya, orangtua menuntut lembaga PAUD untuk mengajari anak membaca, menulis, serta berhitung (calistung) karena khawatir anaknya tidak mampu mengikuti pelajaran di sekolah jika sedari awal belum dibekali keterampilan calistung, sehingga guru PAUD terpaksa mengekploitasi kecerdasan anak.

Permasalahan calistung terjadi jika pembelajaran diajarkan seperti orang dewasa, besar kemungkinan hal itu berakibat fatal. Anak bisa kehilangan semangat karena menganggap pelajaran itu sulit dan tidak menyenangkan walaupun setiap anak sering bersentuhan dengan kasus matematis, seperti: Berapa jumlah jari tangan? Berapa jumlah roda mobil? Berapa hari seminggu, sebulan, serta setahun? Berapa jumlah anggota keluarga? Namun, sangat disayangkan karena tidak diimbangi dengan penguasaan yang sesuai, banyak anak di sekolah merasa lemah dalam mata pelajaran matematika, sekalipun setiap hari terus berhadapan dengan kasus matematika. Inilah yang perlu dicermati oleh guru dan orangtua mengapa matematika jauh dari penguasaan keilmuan, padahal dekat dengan kehidupan.

Oleh sebab itu, diperlukan suatu cara untuk mengembangkan kecerdasan logika-matematika. Salah satu metode adalah biblioterapi, yakni terapi buku. Buku menjadi media yang praktis digunakan dan terjangkau, yang telah dikenal sejak zaman Yunani Kuno. Ide pemanfaatan bahan bacaan sebagai media terapi pada waktu itu tak dapat dilepaskan dari Plato. Menurutnya, orang dewasa sebaiknya menyeleksi cerita yang diperdengarkan pada anak mereka, sebab hal itu dapat menjadi jalan berpikir serta budi pekerti anak di masa selanjutnya. Biblioterapi (dalam Anafiah, 2017) berasal dari katabiblionyang berarti buku atau bahan bacaan, sementara therapeia artinya penyembuhan. Jadi, biblioterapi dapat dimaknai sebagai upaya penyembuhan lewat buku. Bahan bacaan berfungsi mengalihkan orientasi dan memberikan pandangan positif. Menurut Suparyono, "pemanfaatan buku sebagai media terapi disebut dengan biblioterapi" (dalam Apriza, 2017).
Lain halnya menurut Agustina (2017: 51) "biblioterapi adalah terapi buku atau membaca dengan metode bercerita, berkisah atau mendongeng untuk menyelesaikan masalah." Buku merupakan guru yang paling sabar dalam memberikan pemahaman dan bisa dibaca berulang-ulang, hingga pembacanya menemukan kunci terbaik untuk menyelesaikan masalahnya.

Praktik biblioterapi sangat efektif dikenalkan melalui metode mendongeng. Logikamatematika dongeng mudah dipahami anak-anak karena sesuai dengan perkembangannya. Anakanak sering merasa lebih mudah mengerti matematika melalui cerita daripada dengan angka-angka. Saat anak sedang membaca atau mendengarkan dongeng, sesungguhnya anak sedang melakukan pemikiran logika yang berhubungan dengan mempolakan, menganalisis, serta menyimpulkan isi cerita. Aspek logika dan matematika selalu ada dalam dongeng, sekalipun tidak kompleks. Aspek matematika terkait dengan permainan angka yang sering muncul dalam dongeng serta logika terkait dengan rangkaian peristiwa. Untuk itu, dongeng punya potensi dijadikan media peningkatan kecerdasan logikamatematika. Bahkan kenyataan yang tidak bisa disangkal, anak-anak akan lebih memahami logika dan matematika dalam cerita. Saat anak sedang membaca atau mendengarkan dongeng, sesungguhnya anak sedang melakukan pemikiran logika terkait dengan mempolakan, menganalisis, dan menyimpulkan isi cerita. Ini berarti melalui dongeng, anak diajak untuk mengembangkan kecerdasan logis-matematis.

\section{METODE}

Penelitian mengenai biblioterapi untuk peningkatan kecerdasan logika-matematika menggunakan PTK atau Classroom Action Research. Menurut Suyitno (Hendriana \& Afrilianto, 2014: 31), "penelitian tindakan kelas merupakan studi sistematis yang dilakukan oleh guru dalam upaya memperbaiki praktik-praktik pendidikan dengan melakukan tindakan praktis serta refleksi dari tindakan tersebut."

Tujuan PTK yakni untuk memperbaiki dan meningkatkan kualitas isi, masukan, proses, serta hasil pembelajaran.Penelitian Tindakan Kelas memiliki dua siklus yaitu siklus I (pertemuan 


\section{JURNAL CERIA}

satu, dua dan tiga) serta siklus II (pertemuan satu, dua, dan tiga). Teknik pengumpulan data yaitu observasi, wawancara,serta dokumentasi.

Penelitian ini dilakukan di Kober Warna Plus Cimahi beralamat di Jl. Kecamatan No. 95 Cimahi, dilaksanakan bulan Februari sampai April 2018 dengan subjeknya kelompok usia 4-5 tahun, dengan jumlah murid 8 anak, 4 laki-laki dan 4 perempuan.

Analisis data penelitian ini merupakan deskritif data kuantitatif dan kualitatif. Data kualitatif untuk menggambarkan informasi tentang kemampuan anak yang sedang ditingkatkan dalam bentuk kalimat, sedangkan kuantitatif digunakan untuk menganalisa berupa angka. Pada penelitian ini, peneliti menggunakan rumus penilaian menurut Sudijono (2017: 43) sebagai berikut:

\section{Keterangan:}

$$
\mathrm{P}=\frac{f}{N} \mathrm{x} 100 \%
$$

$\mathrm{f}=$ Frekuensi yang sedang dicaripersentasenya

$\mathrm{N}=$ Jumlah frekuensi banyaknya individu

$\mathrm{P}=$ Angka persentasi

PTK ini mengikuti model Kemmis dan Mc Taggart (Hendriana \& Afrilianto, 2014) meliputi empat tahap yaitu:

1. Siklus Pertama a) Perencanaan adalah melakukan perencanaan penelitian, b) Pelaksanaan adalah melaksanakan tindakan terhadap objek penelitian, c) Observasi yaitu melakukan pengamatan pada pemberian tindakan dan implikasinya pada subjek penelitian, serta d) Refleksi yakni mengkaji kembali hasil pengamatan terhadap subjek penelitian.

2. Siklus kedua dilakukan dengan langkahlangkah yang sama seperti siklus pertama, namun dilakukan perbaikan dan modifikasi.

Keberhasilan penelitian dilihat dari segi hasil tindakan, dikategorikan berhasil apabila minimal $75 \%$ peserta didik berkembang sangat baik dalam peningkatan kecerdasan logikamatematika.Hal ini merupakan ketentuan Musyawarah dari guru, peneliti, dan kepala Kober Warna Plus.

\section{HASIL PENELITIAN DAN PEMBAHASAN}

\section{Hasil Penelitian}

\section{Kondisi awal}

Hasil observasi pra siklus adalah sebagai berikut:

a. Kemampuan kanak-kanak mengenal konsep sederhana kehidupan sehari-hari untuk kategori yang Belum Berkembang (BB) 3 anak, kategori Mulai Berkembang (MB) 4 anak, Berkembang Sesuai Harapan (BSH) 1 anak, serta tidak ada anak Berkembang Sangat Baik (BSB).

b. Memahami pola kegiatan dan menyadari pentingnya waktu untuk BB tidak ada, MB 4 anak, BSH 3 anak, dan 1 anak BSB.

c. Mengetahui konsep banyak dan sedikit untuk kategori BB tidak ada, MB 4 anak, BSH 3 anak, serta 1 anak BSB.

d. Mengenal warna untuk kategori BB) 1 anak, MB 3 anak, 1 anak BSH, dan 3 BSB.

e. Mengenal pola untuk kategori BB sebanyak 4 anak, MB 3 anak, BSH 1 anak, 0 BSB.

f. Mengurutkan benda berdasarkan 5 seriasi ukuran atau warna, untuk kategori BB 4 anak, MB 3 anak, BSH 1 anak, dan 0 BSB.

g. Kemampuan siswa menyebutkan lambang bilangan 1-10 untuk kategori yang BB 1 anak, MB 4 anak, BSH 2 anak, serta 1 anak BSB.

h. Menggunakan lambang bilangan untuk menghitung, BB sebanyak 4 siswa, MB 3 anak, 1 anak didik BSH, dan 0 BSB.

i. Kemampuan peserta didik mencocokkan bilangan dengan lambang bilangan untuk kategori BB sebanyak 4 anak, MB 3 anak, 1 anak BSH, serta tidak ada anak yang BSB.

\section{Tabel 1 Persentase Pra Siklus}

\begin{tabular}{lc}
\hline Kategori & Pra Siklus \\
\hline BB & $50 \%$ \\
MB & $12,5 \%$ \\
BSH & $25 \%$ \\
BSB & $12,5 \%$ \\
\hline Total & $100 \%$ \\
\hline
\end{tabular}

Hasil observasi kondisi awal yaitukategori BB sebesar 50\%, MB 12,5\%, BSH 25\%, dan BSB 12,5\%. Hal ini menunjukkan bahwa kecerdasan logika-matematika peserta didik 


\section{JURNAL CERIA}

ISSN : 2614-6347 (Print) 2614-4107 (Online)

Vol.1| No.4 I Juli 2018

kelompok A Kober Warna Plus belum berkembang optimal sehingga dibutuhkan tindakan yang dapat meningkatkan kemampuan logis-matematis yakni melalui biblioterapi.

Hasil pra siklus belum optimal karena beberapa faktor diantaranya: sebagian anak tidak memerhatikan guru, adasiswa mengobrol, serta guru kurang jelas menyampaikan materi.

\section{Siklus I}

\section{a. Perencanaan}

Tahap ini yaitu pembuatan RPPH berdasarkan silabus yang dijadikan acuan penelitian, kemudian disusun skenario pembelajaran untuk setiap pertemuan. Penerapan biblioterapi pada siklus pertama dilakukan dengan metode mendongeng, tanya jawab, percakapan, penugasan, unjuk kerjadan instrumen berupa lembar observasi, wawancara, serta dokumentasi.

\section{b. Pelaksanaan}

Tindakan pembelajaran siklus 1 yaitu 3 pertemuan pada tanggal 5, 6,7 Maret 2018 serta satu kali tes, yang dilakukan oleh peneliti dan guru kelas kelompok A Kober Warna Plus secara bersama-sama melakukan biblioterapi.

\section{c. Observasi dan Evaluasi}

Hasil observasi siklus I sebagai berikut:

1) Kemampuan anak mengenal konsep sederhana kehidupan sehari-hari untuk kategori BB tidak ada, MB 3 anak, BSH 4 anak, serta 1 anak BSB.

2) Memahami pola kegiatan serta menyadari pentingnya waktu untuk kategori $\mathrm{BB} 0, \mathrm{MB} 0$, BSH 4 anak, serta 4 BSB.

3) Mengetahui konsep banyak dan sedikit, untuk kategori BB 0, MB 0, BSH 4 anak, serta 4 anak BSB.

4) Mengenal warna untuk kategori $\mathrm{BB}$ 0,1 anak MB, BSH 3 anak, dan 4 anak BSB.

5) Kemampuan mengenal pola, BB 0, 4 anak $\mathrm{MB}, 4$ anak BSH, serta 0 BSB.

6) Mengurutkan benda berdasarkan lima seriasi ukuran atau warna, BB 0, 4 anak MB, 4 anak BSH, dan 0 BSB.

7) Kemampuan siswa menyebutkan lambang bilangan 1-10,BB 1 anak, MB 3 anak, BSH 3 anak, serta 1 anak BSB.
8) Kemampuan menggunakan lambang bilangan untuk menghitung, yaitu BB sebanyak 3 anak, MB 4 anak, tidak ada anak BSH, dan 1 anak BSB.

9) Mencocokkan bilangan dengan lambang bilangan, untuk BB 3 anak, MB 4 anak, tidak ada anak BSH, serta 1 anak BSB.

Tabel 2 Persentase Siklus 1

\begin{tabular}{lc}
\hline Kategori & Pra Siklus \\
\hline BB & $0 \%$ \\
MB & $50 \%$ \\
BSH & $37,5 \%$ \\
BSB & $12,5 \%$ \\
\hline Total & $100 \%$ \\
\hline
\end{tabular}

Berdasarkan hasil observasi siklus pertama, anak Belum Berkembang 0\%, Mulai Berkembang 50\%, Sesuai Harapan 37,5\%, serta Sangat Baik 12,5\%.Anak didik yang mampu menunjukkan penguasaan kecerdasan logikamatematika semakin bertambah dibandingkan kondisi awal.

\section{d. Refleksi}

Tahap ini, peneliti dan guru menilai serta mendiskusikan kelemahan yang terdapat pada pelaksanaan tindakan siklus I. Penerapan biblioterapi belum optimal, mengingat kegiatan ini baru dilakukan di kelompok A Kober Warna Plus.

Beberapa kelemahan tersebut antara lain:tidak semua siswa aktif belajar, oleh sebab masih ada beberapa anak tidak memerhatikan guru dan lebih asyik dengan yang dilakukan anak di luar pembelajaran, sebagiananak masih mengalami kesulitan memahami pelajaran kecerdasan logika-matematika, serta masih banyaknya peserta didik yang mudah teralihkan perhatiannya ketika kegiatan biblioterapi dilaksanakan.

\section{Siklus II}

\section{a. Perencanaan}

Peneliti bersama guru merencanakan tindakan siklus II, agar beberapa kelemahan yang 
terjadi sebelumnya dapat diperbaiki serta memperoleh hasil maksimal.Kemudian disusun skenario pembelajaran untuk setiap pertemuan yang dilakukan dengan metode mendongeng, tanya jawab, percakapan, penugasan, unjuk kerja, dan hasil karya.

Membuat lembar observasi anak (aspek yang diobservasi didasarkan langkah-langkah pembelajaran pada RPPH),menyiapkan perangkat pembelajaran sebagai media yang akan digunakan saat pembelajaran biblioterapi serta merancang perangkat evaluasi untuk tes tindakan siklus II.

\section{b. Pelaksanaan}

Tindakan pembelajaran siklus II yaitu 3 pertemuan pada tanggal 2, 3, dan 4 April 2018 serta satu kali tes. Guru tetap bertindak sebagai pengajar sedangkan peneliti menjadi pengamat.

\section{c. Observasi dan evaluasi}

Hasil pelaksanaan siklus II sebagai berikut:

1) Kemampuan mengenal konsep sederhana kehidupan sehari-hari, untuk kategori BB dan MB tidak ada, BSH 3 anak, serta 5 anak BSB.

2) Mengenal pola kegiatan serta menyadari pentingnya waktu, BB, MB, serta BSHtidak ada, semua siswa yang berjumlah 8 anak masuk kategori BSB.

3) Mengetahui konsep banyak dan sedikit, untuk kategori BB serta MB tidak ada, BSH 1 anak, dan 7 BSB.

4) Mengenal warna, untuk kategori $\mathrm{BB}$ dan $\mathrm{MB}$ tidak ada, BSH 1 anak, serta 7 anak BSB.

5) Mengenal pola, BB tidak ada, 1 anak MB, 3 anak BSH, dan sebanyak 4 anak BSB.

6) Mengurutkan benda berdasarkan lima seriasi ukuran atau warna, kategori BB tidak ada, 1 anak MB, 4 anak BSH, dan 3 anak BSB.

7) Menyebutkan lambang bilangan 1-10, untuk BB dan MB 0, BSH 2 anak, serta 6 anak BSB.

8) Menggunakan lambang bilangan untuk menghitung, kategori anak BB tidak ada, MB 1 anak, 4 anak BSH, serta 3 anak BSB.

9) Mencocokkan bilangan dengan lambang bilangan, untuk kategori BB tidak ada, MB 1 anak, 6 anak BSH, serta 1 anak BSB.

\section{Tabel 3 Persentase Siklus II}

\begin{tabular}{lc}
\hline Kategori & Pra Siklus \\
\hline BB & $0 \%$
\end{tabular}

\begin{tabular}{ll} 
MB & $0 \%$ \\
BSH & $12,5 \%$ \\
BSB & $87,5 \%$ \\
\hline Total & $100 \%$ \\
\hline
\end{tabular}

\section{Pembahasan}

\section{Logika-Matematika Peserta Didik Sebelum Diterapkan Biblioterapi di Kober Warna Plus}

Sebelum dilaksanakan tindakan siklus I, terlebih dahulu anak kelompok A diberi tes awal sebagai latihan yang bertujuan untuk mengetahui pengetahuan siswa. Hasil penelitian awal menunjukkan di bawah rata-rata dari jumlah maksimal seluruh anak didik yakni $12,5 \%$ BSB sebanyak 1 anak, 25\% BSH 2 anak, 1 anak MB sebesar 12,5\%, dan 4 anak belum mampu menguasai materi kecerdasan logika-matematika sebesar 50\%. Tentu hal ini mengharuskan adanya suatu tindakan pembelajaran agar dapat meningkatkan kecerdasan logis-matematis.

\section{Pelaksanaan Biblioterapi dalam Peningkatan Kemampuan Kecerdasan Logika-Matematika Siswa di Kober Warna Plus.}

Biblioterapi adalah terapi buku atau membaca dengan metode bercerita, berkisah atau mendongeng untuk menyelesaikan masalah (Agustina, 2017). Biblioterapi digunakan agar dapat meningkatkan kecerdasan logikamatematika anak kelompok A Kober Warna Plus pada pra siklus belum menguasai dengan baik indikator kecerdasan logis-matematis. Untuk itu peneliti bersama guru kelas mengadakan tindakan siklus I dan II.

Berdasarkan pelaksanaan pembelajaran kecerdasan logis-matematis malalui biblioterapi untuk siklus I, menunujukkan hasil bahwa pembelajaran belum optimal dilaksanakan sesuai skenario yang telah disusun serta disepakati antara peneliti dan guru.

Secara umum untuk siklus I terdapat beberapa kekurangan, yaitu tidak semua anak aktif pada kegiatan pembelajaran, banyak anak terdiam saat kegiatan tanya jawab, ada siswa yang masih terlihat malu-malu atau ragu untuk menyebutkan dan menjawab pertanyaan dalam 


\section{JURNAL CERIA}

ISSN : 2614-6347 (Print) 2614-4107 (Online)

Vol.1 1 No.4

kegiatan biblioterapi, serta anak mengemukakan pendapat masih belum optimal.

Hasil tes tindakan siklus pertama menunjukkan bahwa penguasaan materi kecerdasan logika-matematika melalui biblioterapi secara klasikal hanya 12,5\% sangat baik, 37,5\% sesuai harapan, dan 50\% mulai muncul perkembangannya serta masih harus distimulasi. Hal ini menunujukkan peningkatan ketika tes awal dilakukan.

Berdasarkan hasil observasi pelaksanaan tindakan untuk siklus II melalui biblioterapi menggunakan metode mendongeng, bercakapcakap, tanya jawab, serta penugasan sudah jauh cukup baik dari sebelumnya. Guru memperbaiki kekurangan dan kelemahan-kelemahan pelaksanaan tindakan sebelumnya serta menciptakan suasana pembelajaran yang bervariasi agar anak didik tidak merasa bosan walaupun masih menggunakan biblioterapi untuk pembelajaran. Ini terlihat dari keaktifan dan rasa antusias dari siswa dalam merespon kegiatan yang diberikan guru. Namun kekurangan guru yang banyak terjadi adalah membatasi anak untuk mengemukakan pendapatnya.

Berdasarkan hasil observasi terhadap siswa pada siklus II menunjukkan bahwa penguasaan kecerdasan logika-matematika anak melalui biblioterapi secara klasikal telah mengalami peningkatan. Sebelumnya, pada tes tindakan siklus I hasilnya baru mencapai $12,5 \%$ BSB serta $37,5 \%$ BSH, namun pada saat dilakukan tes siklus II hasilnya siswa sudah mampu menunujukkan kemampuannya dengan Berkembang Sangat Baik yaitu 87,5\% dan Sesuai Harapan $12,5 \%$.

\section{Hasil Setelah Diterapkan Biblioterapi dalam Peningkatan Kecerdasan Logika- Matematika Anak Didik di Kober Warna Plus.}

Hasil penelitian dari pra siklus, siklus I serta II pada pelaksanaan pembelajaran biblioterapi dapat meningkatkan kecerdasan logis-matematis anak, terbukti dengan anak mampu menguasai indikator kecerdasan logismatematis yaitu keterampilan berhitung, berpikir logika, serta pemecahan masalah. Hal ini sejalan dengan pengertian kecerdasan logis-matematis menurut Shearer (Susanto, 2015: 282) menyatakan bahwa "kecerdasan logikamatematika meliputi keterampilan berhitung, berpikir logis, dan pemecahan masalah." Hal ini diperkuat oleh Permendikbud RI No 137 (2014) bahwa, "indikator kecerdasan logis-matematis untuk anak usia empat sampai lima tahun dalam perkembangan kognitif adalah belajar sertapemecahan masalah meliputi mengenal konsep sederhana kehidupan sehari-hari, memahami pola kegiatan serta menyadari pentingnya waktu, mengetahui konsep banyak dan sedikit; berpikir logis yaitu mengenal warna serta pola,mengurutkan benda berdasarkan lima seriasi ukuran atau warna; dan berpikir simbolik meliputi menyebutkan lambang bilangan 1-10, menggunakan lambang bilangan untuk menghitung, serta mencocokkan bilangan dengan lambang bilangan.

Penilaian data secara keseluruhan dari hasil observasi pada pra siklus, siklus I serta II di atas sebagai berikut:

Tabel 4

Persentase Tes Pra Siklus, Siklus I, Siklus II

\begin{tabular}{lccc}
\hline Kategori & Pra Siklus & $\begin{array}{c}\text { Siklus } \\
\text { I }\end{array}$ & $\begin{array}{c}\text { Siklus } \\
\text { II }\end{array}$ \\
\hline BB & $50 \%$ & $0 \%$ & $0 \%$ \\
MB & $12,5 \%$ & $50 \%$ & $0 \%$ \\
BSH & $25 \%$ & $37,5 \%$ & $12,5 \%$ \\
BSB & $12,5 \%$ & $12,5 \%$ & $87,5 \%$ \\
\hline Total & $100 \%$ & $100 \%$ & $100 \%$ \\
\hline
\end{tabular}

\section{Grafik 1}

Persentase Tes Pra Siklus, Siklus I, Siklus II

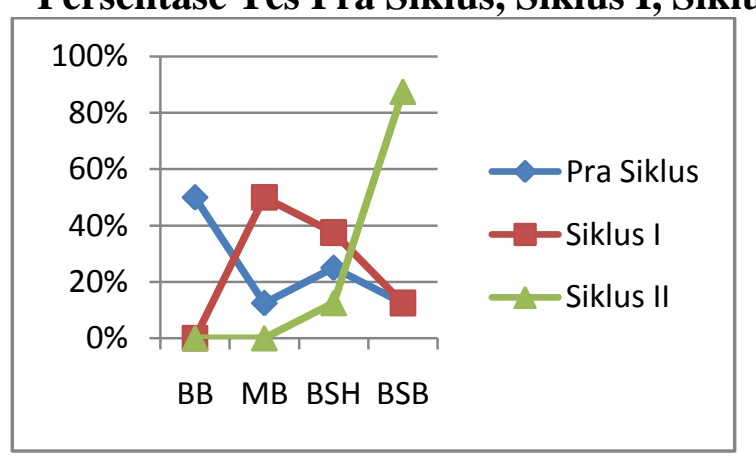

Berdasarkan Tabel 7 dan Grafik 1 di atas, hasil observasi telah mengalami perubahan dari awal pra siklus sampai dilakukannya tindakan 
siklus II. Pada tes awal BB 50\%, MB 12,5\%, anak BSH 25\%, dan BSB 12,5\%. Namun setelah diberikan tindakan siklus I, BB 0\%, MB 50\%, BSH $37,5 \%$, sertaBSB $12,5 \%$. Kemudian pada tindakan siklus II mengalami perubahan yang sangat baik di akhir siklus yaitu BB 0\%, MB 0\%, BSH 12,5\%, dan BSB 87,5\%.

Untuk itu dengan ini dinyatakan bahwa kemampuan kecerdasan logika-matematika anak kelompok A Kober Warna Plus telah mengalami peningkatan yang sangat baik melalui biblioterapi.

\section{SIMPULAN}

Penelitian ini dapat disimpulkan bahwa kondisi objektif kecerdasan logis-matematispeserta didik kelompok A di Kober Warna Plus sebelum diberikan tindakan yaitu masih banyak anak yang belum mampu mencapai indikator kecerdasan logika-matematika. Hasil penelitian awal menunjukkan kemampuan anak di bawah ratarata dari jumlah maksimal seluruh anak yakni $12,5 \%$ Berkembang Sangat Baik, 25\% Berkembang Sesuai Harapan, dan 12,5\% Mulai Berkembang, dan $50 \%$ belum mampu menguasai materi kecerdasan logika-matematika.

Hasil penelitian setelah diterapkan biblioterapi menunjukkan peningkatan dari sebelum diberi tindakan. Pada siklus I serta II, kecerdasan logika-matematika anak berkembang secara optimal. Pada siklus I, anak BSB 12,5\%, BSH $37,5 \%$, MB 50\%, dan 0\% BB. Sedangkan pada siklus II, kecerdasan logika-matematika mengalami peningkatan pada kategori BSB $87,5 \%$, BSH $12,5 \%$, serta $0 \%$ kategori $\mathrm{MB}$ dan BB.Berdasarkan hasil observasi dari setiap tindakan pada siklus, dapat disimpulkan bahwa dengan biblioterapi dapat meningkatkan kecerdasan logika-matematika anak didik kelompok A di Kober Warna Plus.Pelaksanaan biblioterapi menunjukkan hasil bahwa sebagian besar anak sangat antusias mengikuti pembelajaran.Selain dapat meningkatkan kecerdasan logika-matematika anak, biblioterapi dapat meningkatkan kecerdasan bahasa, kognitif, agama, dan sosial emosional.

\section{SARAN}

Peneliti menyarankan agar orangtua, guru, dan pihak sekolah mengajarkan kecerdasan logikamatematika dengan cara yang menyenangkan, mudah, kreatif, dan menunjukkan contoh-contoh sederhana pada anak yang berhubungan dengan logika-matematika agar anak lebih termotivasi untuk belajar tanpa paksaan.

\section{DAFTAR PUSTAKA}

Agustina, S. (2017). Biblioterapi untuk Pengasuhan Membangun Karakter Anak dengan Kisah.Jakarta: PT Mizan Publika.

Afriza (2017).Pengaruh Biblioterapi Dengan Buku Cerita Bergambar Terhadap Tingkat Kecemasan Efek Hospitalisasi pada Anak Prasekolah.Jurnal Pendidikan Ke-SD-an, Vol. 3, Nomor 3. Retrieved from http://journal.stkiptam.ac.id/index.php/obse $\underline{\text { si }}$

Anafiah, Siti. (2017). Pemanfaatan Cerita Rakyat Sebagai Media Biblioterapi bagi Anak.Trihayu: Jurnal Pendidikan Ke-SDan, Vol. 3, Nomor 3, Mei 2017, hlm. 139143. Retrieved from: http://jurnal.ustjogja.ac.id/index.php/trihayu /article/view/1875/1044

Hendriana, H., \& Afrilianto, M. (2014).Panduan bagi Guru Penelitian Tindakan Kelas suatu Karya Tulis Ilmiah.Bandung: PT Refika Aditama.

Kurniawan, Heru (2016). Kreatif Mendongeng untuk Kecerdasan Jamak Anak.Jakarta: Kencana.

Permendikbud RI No 137 (2014). Lampiran I, Standar Nasional Pendidikan Anak UsiaDini,h 24-26. https://www.paud.id/2015/03/downloadpermendikbud-137-tahun-2014-standarpaud.html

Sudijono, Anas (2017). Pengantar Statistik Pendidikan.Jakarta: RajaGrafindo Persada. Susanto, A. (2015). Bimbingan dan Konseling di Taman Kanak-Kanak.Jakarta:

Prenadamedia Grup. 


\section{JURNAL CERIA}

ISSN : 2614-6347 (Print) 2614-4107 (Online)

Vol.1 | No.4 ل Juli 2018

Suyadi \& Maulidya, U. (2013). Konsep Dasar

PAUD. Bandung: PT Remaja Rosdakarya 